\title{
ABILITY OF MICROSCOPIC FUNGI, RECOMNENDED FOR THE ESTIMATION OF FUNGINERTNESS OF TECHNICAL MATERIALS, TO FORM HYDROLASES
}

\author{
A.I. Chuienko, Yu.B. Pysmenna \\ Zabolotny Institute of Microbiology and Virology, NAS of Ukraine, \\ 154 Akad. Zabolotny Str., Kyiv, 03143, Ukraine \\ e-mail:helmhammer@ukr.net
}

\begin{abstract}
Aim. To estimate an activity of hydrolases of test-cultures of microscopic fungi that is applied for tests from funginertness of technical wares and materials. Methods. Enzymatic activities (of complexes of cellulases, amylases, lipases and proteases) determined in accordance with the methods, based on reactions between dye, that bring into medium or on a colony and the product of curriculum of substrate and expected enzymatic index. Results. It has been edused that all investigational isolates were characterized by the presence at least of one enzymatic activity (cellulase, amylase, lipase or protease) Conclusions. It has been established that enzymatic activities of isolates, except for C. globosum of F - 16714, did not depend on a their expiration and source of selection date.. It has been educed that A. versicolor F-41469 had the highest values of cellulase and amylase activity, A. pullulans F-159 and C. cladosporioides F-41230 - cellulase and lipase, P. aurantiogriseum F-1644, P. chrysogenum F-16719 and P. funiculosum - amylase and lipase, H. resinae F-16724, P. variotii F-16724-amylase, C. sphaerosphermum (F-41232. F-2442) and P. ochrochloron $F-16715$-lipase. It has been ascertained that swingeing majority of strains isolated from gypsum plasterboard are potential destructors of it basic components.
\end{abstract}

Keywords: funginertness, gypsum plasterboard, hydrolases, enzymatic index, biodestruction.

Technical wares and materials are widely applied in many branches of industry, medicine, building and way of life. Often enough, especially in the conditions of an increased humidity of air, such materials are deteriorated by microscopic fungi. It results to the loss of them original appearance and decline of row of physical and technical descriptions [1]. In addition, development of fungi on the damaged materials, create a threat for the human health. Most micromycetes are producers of mycotoxins and causative agents of human diseases [2-4].

Therefore for prevention of origin of biodamages the producers of technical wares and materials must own reliable information on their funginertness.

The item of rational selection of test-cultures for determination of the funginertness of different technical wares and materials question had been considered in scientific literature [5-7]. Among the row of such indexes, as an unconcern of test-cultures for human and absence of mutual antagonism, an important place occupies their ability to form hydrolases. In opinion of some authors, such property of microscopic fungi allows them to assimilate new substrates and survive in extreme terms [8].

It is known that the protracted storage and frequent passages of microorganisms can reduce an activity of their enzymes and other metabolites 
[9]. It, in turn, can result declining of intensity of fungal growth on the surface of material that passes a test for funginertness, and reception of improper data.

In this connection the aim of this work was to estimate the fitness of testcultures of microfungi from collection of the Testing laboratory of funginertness and microbiological investigation of technical, medical wares and materials of D.K. Zabolotny Institute of Microbiology and Virology NASU (TL IMV NASU) by the screening of their hydrolases. As a criteria of fitness of testculture considered its ability to form at least one enzyme.

Materials and methods. 31 strains of the microfungi isolated from different natural and technogenic substrates were used as objects of research. Among them 21 cultures were recommended by standards for determination of funginertness of technical wares and materials [10-14]. These cultures stored for a long period of time (8-30 years) in the collection if TL IMV NASU and reseed every year. Other 10 strains of micromycetes were isolated from the gypsum pasteboard of different brands during 2010-2011 pp. [15] and were reseeded one time (Table).

Test-cultures of microscopic fungi were stored on potato-glucose agar (PGA), potato-carrot agar (PCA) and agarized mesh ( $4,5^{\circ}$ sensu Balling) in the cool storage at $5 \pm 2{ }^{\circ} \mathrm{C}$. Before the experiment, the cultures were seeded at the aforementioned sheared media and incubated in a thermostat at $29 \pm 2{ }^{\circ} \mathrm{C}$ $[13,16]$.

Table

Sources of isolation of investigated microscopic fungi

\begin{tabular}{|c|c|c|c|c|}
\hline № & Source of isolation & Year & Name of specie & Strain number \\
\hline 1. & Aviation fuel & 2002 & Hormoconis resinae & F-2494 \\
\hline 2. & Cotton & 1998 & Chaetomium globosum & F-16714 \\
\hline \multirow{10}{*}{3.} & \multirow{10}{*}{ Gypsum plasteboard } & \multirow{4}{*}{2010} & Aspergillus fisheri & F-41212 \\
\hline & & & A. flavipes & F-41213 \\
\hline & & & A. niger & F-4122 \\
\hline & & & Trichoderma viride & F-41225 \\
\hline & & \multirow{6}{*}{2011} & Alternaria infectoria & F-41218 \\
\hline & & & A. versicolor & F-41226 \\
\hline & & & C. globosum & F-41224 \\
\hline & & & Cladosporium cladosporioides & F-41230 \\
\hline & & & C. sphaerospermum & F-41232 \\
\hline & & & Stachybotrys chartarum & F-41215 \\
\hline \multirow{2}{*}{4.} & \multirow{2}{*}{ Rubber crumb } & \multirow{2}{*}{2008} & A. flavus & F-41432 \\
\hline & & & A. versicolor & F-41469 \\
\hline 5. & \multirow{4}{*}{ Soil } & 2000 & Penicillium aurantiogriseum & F-1644 \\
\hline \multirow{2}{*}{6.} & & \multirow{2}{*}{2003} & C. sphaerospermum & F-2442 \\
\hline & & & T. köningii & F-2465 \\
\hline 7. & & 2004 & Paecilomyces variotii & F-16724 \\
\hline 8. & Grain of corn & 1997 & $\begin{array}{l}\text { Fusarium moniliforme } \\
\text { (syn. F. verticilloides) }\end{array}$ & F-50466 \\
\hline 9. & Picture, oil & 1998 & P. funiculosum & F-16721 \\
\hline 10. & Feed for birds & 1999 & P.chrysogenum & F-16719 \\
\hline \multirow{2}{*}{11.} & \multirow{2}{*}{ Surface of the metal } & \multirow{2}{*}{1991} & A. flavus & F-16717 \\
\hline & & & P. ochrochloron & F-16715 \\
\hline
\end{tabular}


Table (continuation).

\begin{tabular}{|l|c|c|c|c|}
\hline № & Source of isolation & Year & Name of specie & Strain number \\
\hline \multirow{2}{*}{ 11. } & Surface of the metal & 1991 & Scopulariopsis brevicaulis & F-16716 \\
\cline { 3 - 5 } & & \multirow{2}{*}{1999} & A. niger & F-73001 \\
\cline { 3 - 5 } & & A. terreus & F-16718 \\
\hline 12. & Surface of the metal & 2001 & P. brevicompactum & F-16723 \\
\hline 13. & Air of the museum & 1998 & A. tenuissima & F-16722 \\
\hline 14. & Sewer water & 1986 & Aureobasidium pullulans & F-159 \\
\hline 15. & Cellulose & 1998 & T. viride & F-16713 \\
\hline 16. & Plaster & 2004 & Sarocladium strictum & F-2479 \\
\hline
\end{tabular}

To determine the cellulase activity, the medium of the following composition was prepared, g/l: glucose $-1,0$; peptone $-0,5$; yeast extract $-0,1$; sodium salt of carboxymethylcellulose- 5,0; agar - 16,0. For coloring, Congo red solution was used in concentration $2,0 \mathrm{~g} / 1$ and for washing the colonies from its residues - $1 \mathrm{M}$ solution of sodium chloride [17, 18]. Positive result was the formation of light yellow or dark-colored areas around the colonies of fungi.

Amylase activity was determined on meat-peptone agar (MPA) with the addition of $0.2 \%$ aqueous starch solution. $1 \%$ aqueous solution of iodine was used for coloring. The positive result was the formation of transparent zones around the colonies of fungi $[17,18]$.

Lipase activity was determined on the medium of the following composition, $\mathrm{g} / \mathrm{l}$ : peptone $-10,0 ; \mathrm{NaCl}-5,0 ; \mathrm{CaCl}_{2} \cdot 2 \mathrm{H}_{2} \mathrm{O}-0,1 ;$ agar $-20,0 ;$ Twin- $80-0,1$. Positive result was considered the formation of precipitation zones calcium salts of fatty acids around the colonies of fungi $[17,18]$.

Determination of cellulase, amylase and lipase activity was performed at 7 days of incubation at $29 \pm 2{ }^{\circ} \mathrm{C}$.

The proteolytic activity of the microscopic fungi was determined at 29 and $37^{\circ} \mathrm{C}[3,4]$.

To determine the protease activity, an MPA medium was prepared with the addition of $3,2 \%$ gelatin, which allows for better visualization of the results compared to the existing method (adding $0.4 \%$ gelatin). The positive result was the formation of transparent zones around the colonies of fungi. For better visualization, a $75 \%$ solution of $\left(\mathrm{NH}_{4}\right)_{2} \mathrm{SO}_{4}$ was applied to Petri dishes $[17,18]$.

The enzymatic index (EI) was calculated as the ratio of the diameter of the discolored zone (or sediment zone) to the diameter of the fungus colony [1921]. All studies were conducted in triple repeats, statistical processing of the results was performed using Microsoft Excel 2007.

Results. It has been shown that the majority (93.5\%) of investigated strains of micromycetes are capable of forming a complex of cellulases. Of these, only three strains - A. versicolor F-41469, A. pullulans F-159 and C. cladosporioides F-41230 had an EI higher than 1, 5. Strains $P$. variotii F-16724 i Trichoderma köningii F-2465, isolated from the soil, did not exhibit cellulase activity. Other test cultures had EI within 1,0-1,4 (fig. 1).

It was found that $\mathrm{EI}$ is isolate A. flavus $\mathrm{F}-16717$, which for 25 years was stored in the collection of TL, significantly higher than the EI of isolate A. flavus F-41432, whose shelf life was only 8 years old.

In isolate A. versicolor F-41469 (8 years of storage), EI was approximately 
2.5 times higher than the EI of isolate $A$. versicolor F-41226 (5 years of storage). It should be noted that the isolate $A$. versicolor $\mathrm{F}-41469$ was isolated from the rubber crumb, and A. versicolor F-41226 - from the gypsum plasterboard, which includes cellulose-containing materials.

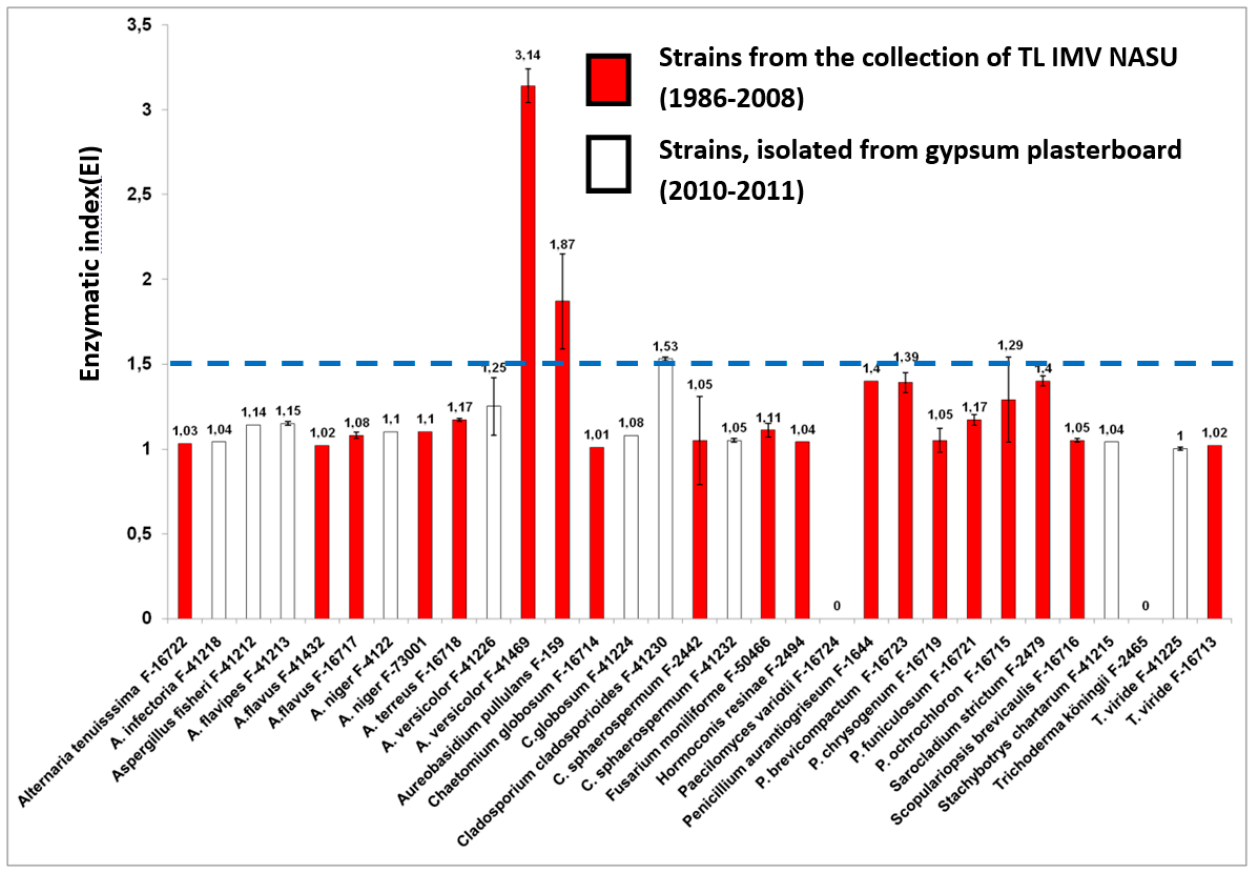

Fig. 1. Enzymatic indices of total cellulase activity of investigated micromycetes $(p>0,95)$

As for C. globosum, it has been shown that the EI of isolate F-41224 (5 years of storage), isolated from gypsum plasterboard, is significantly higher than ES isolate F-16714 (18 years of storage).

There was no significant difference between the EI of pairs of isolates A. niger, $C$. sphaerospermum and $T$. viride, which were characterized by different sources of isolation and storage periods.

Overall amylase activity was detected in $71 \%$ of the studied cultures. Among them both strains of $A$. versicolor (F-41469 та F-16718), H. resinae F-16724, P. variotii F-16724, P. aurantiogriseum F-1644, P. chrysogenum F-16719 i P. funiculosum F-16721 had EI, higher then1,5. Srains of $A$. niger (F-4122, F-73001), C. globosum (F-16714, F-41224), F. moniliforme F-50466, S. brevicaulis F-16716, T. köningii F-2465 and T. viride (F-41225, F-16713) hadn't shown amylase activity. Other test-cultures had an EI within 1.0 - 1.36 (fig.2).

It has been found that EI of strain C. sphaerospermum F-2442 (13 years of storage) isolated from soil is significantly higher than EI of isolate C. sphaerospermum F-41232 (5 years of storage), isolated from gypsum plasterboard, which includes starch and dextrin - substrates that can be decomposed by amylases.

There was no significant difference between the EI pairs of isolates A. flavus and $A$. versicolor, which were characterized by different sources of isolation and storage periods. 




Fig. 2. Enzymatic indices of the total amylase activity of the investigated micromycetes $(p>0,95)$

Total lipase activity has been found in $64.5 \%$ of the studied cultures. Among them, 8 strains - A. pullulans F-159, C. cladosporioides F-41230, both strains C. sphaerosphermum (F-41232 and F-2442), P. aurantiogriseum F-1644, P. chrysogenum F-16719, P. funiculosum F-16721 and P. ochrochloron F-16715 had an EI higher than 1.5 (fig. 3).

Cultures of A. tenuissima F-16722, A. flavus (F-41432 and F-16717), A. niger F-4122, A. terreus F-16718, C. globosum F-41224 and F-16714, F. moniliforme F-50466, H. resinae F-2494 and P. brevicompactum F-16723, hadn't shown lipase activity, other isolates had EI in the range of 1.0-1.44.

There was no significant difference between the EI pairs of isolates A. versicolor, C. sphaerosphermum and $T$. viride, which were characterized by different sources of isolation and storage periods.

The ability to form proteolytic enzymes at $29^{\circ} \mathrm{C}$ was detected in 18 out of 31 studied strains. The highest rates of EI were found in A. versicolor $(1.33$ in both strains) and Scopulariopsis brevicaulis F-16716 - 1.24. In the other 15 isolates, EI was between 1.00 and 1.08 (fig.4).

There was no significant difference between the EI pairs of isolates A. flavus, A. niger, A. versicolor, C. globosum, C. sphaerosphermum and T. viride, which were characterized by different sources of isolation and storage periods.

At $37^{\circ} \mathrm{C}$, only 8 of the 31 isolates formed the protease, with the EI index being low and ranging from 1.00 to 1.08 (fig. 5).

Significant growth of EI for protease activity at an increase in the temperature of cultivation from 29 to $37^{\circ} \mathrm{C}$ hasn't been noted, in addition, 20 of the 31 strains studied hadn't show signs of growth at all. Thus, in most of 
the tested test cultures, there are no virulence factors such as the ability to grow and form proteases at a temperature in the human body $\left(37^{\circ} \mathrm{C}\right)$.

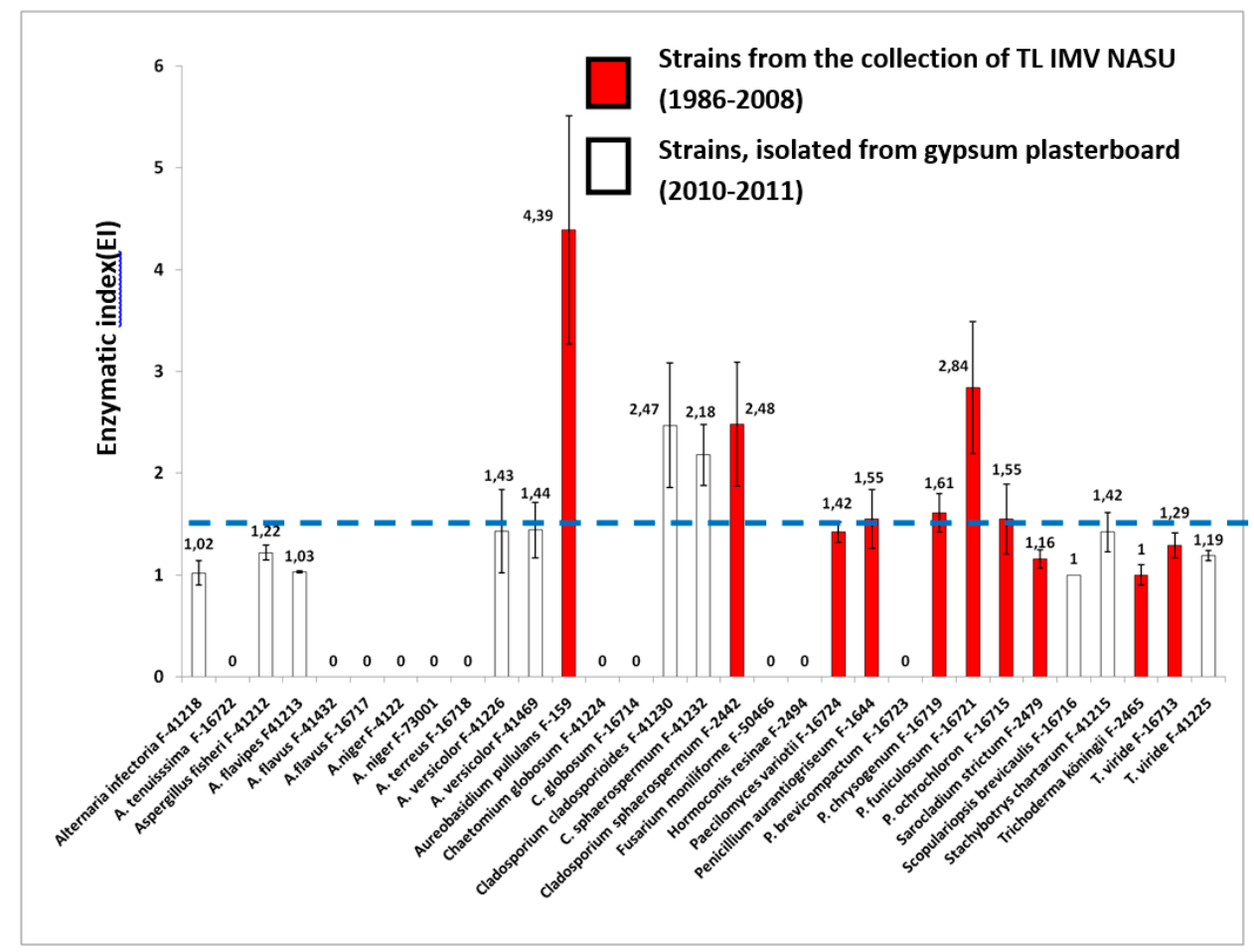

Fig. 3. Enzymatic indices of total lipase activity of the investigated micromycetes $(p>0,95)$

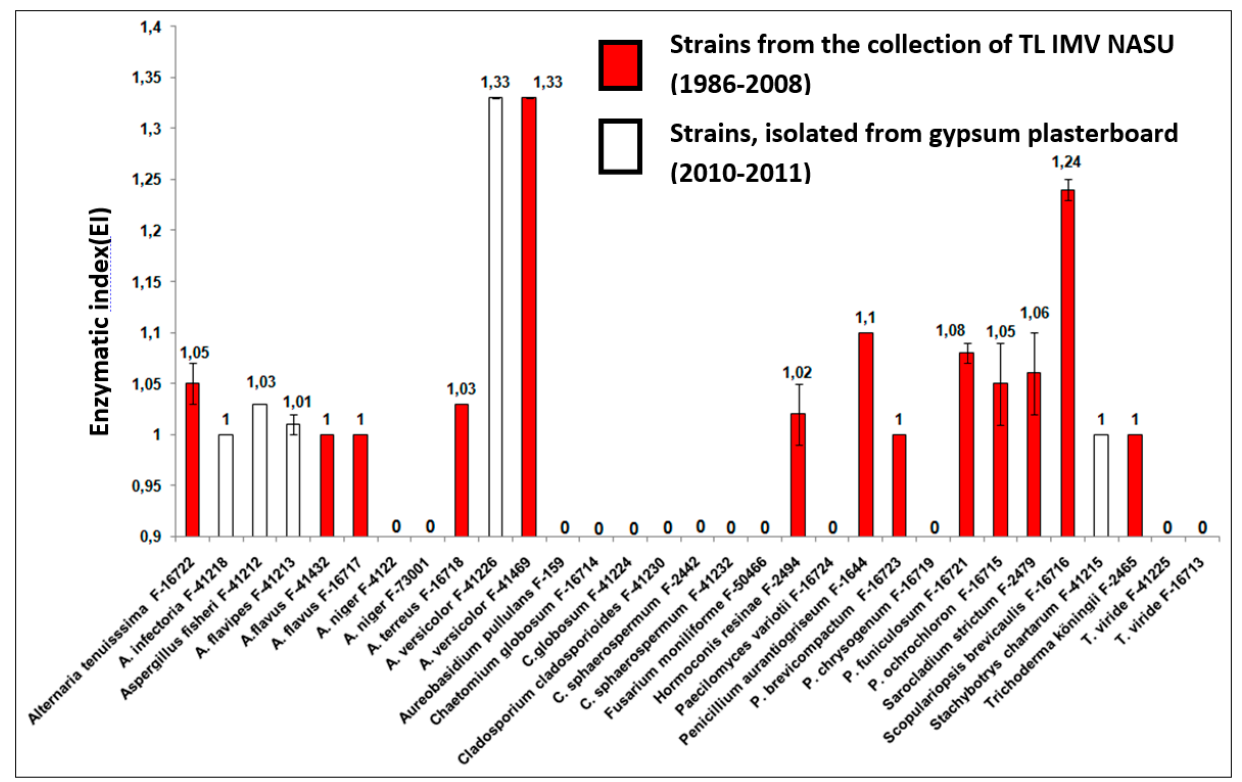

Fig. 4. Enzymatic indices of total protease activity of the investigated micromycetes at $29^{\circ} \mathrm{C}(\mathrm{p}>0,95)$ 


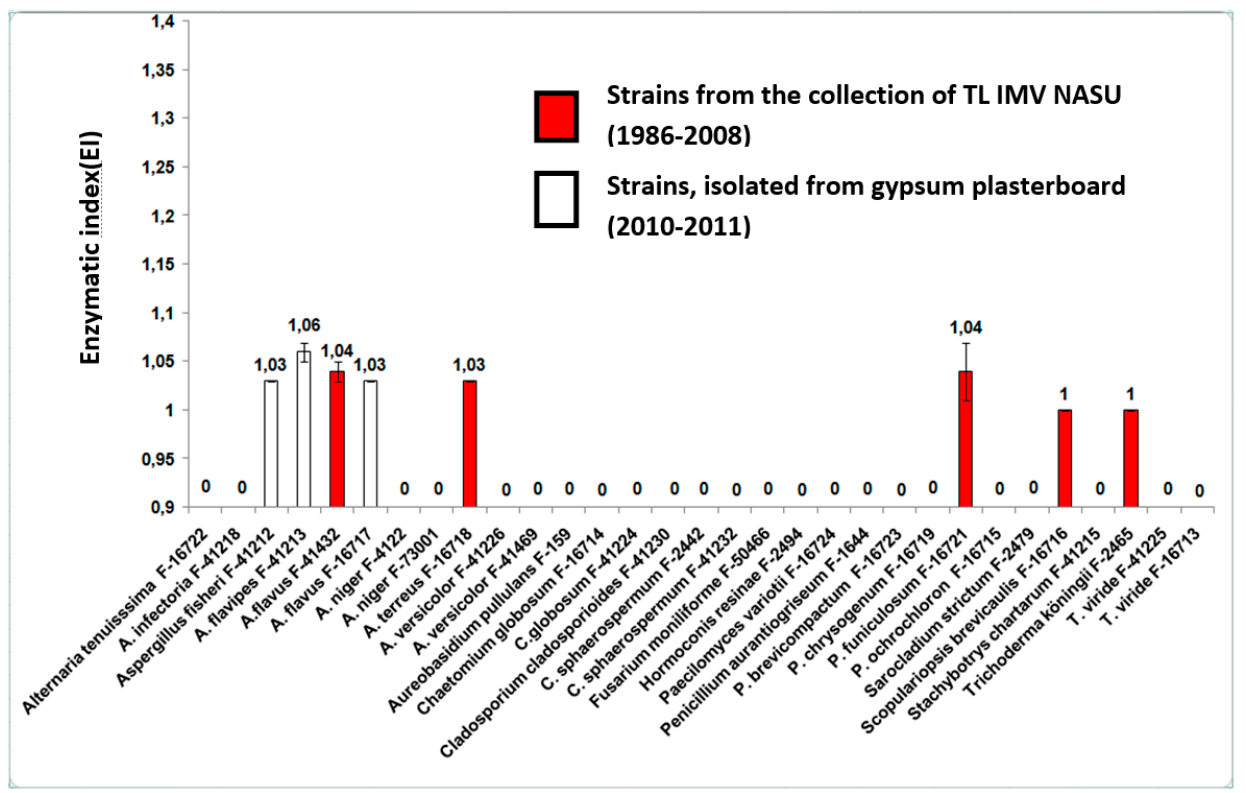

Fig. 5. Enzymatic indices of total protease activity of the investigated micromycetes at $37^{\circ} \mathrm{C}(\mathrm{p}>0,95)$

Discussion. Thus, the EI in the examined 6 pairs of test cultures (A. flavus, A. niger, A. versicolor, C. globosum, C. sphaerospermum and T. viride) by cellulases, amylases, lipases and proteases or not at all depended on the term culture storage, or were significantly higher in strains that were stored in the collection for a longer period of time.

The exception was the enzymatic index of $C$. globosum cellulase activity, which was significantly higher in a culture that had a shorter storage period.

Among the studied 31 cultures at $29^{\circ} \mathrm{C} 5$ were characterized by the presence of only one enzymatic activity, 4 - two activities, 11 - three activities, 10 - all four activities.

So investigated microscopic fungi in ability to form hydrolytic enzymes are characterized by different degree of suitability for use as test-culture in determining the funginertness of technical materials. In our opinion, it is more appropriate to maintain a collection of isolates that are capable of producing several enzymes, since this allows more accurately to assess the funginertness of both single and multi-component materials. It is obvious that periodic testing of the ability to form hydrolytic enzymes is necessary both for test cultures that are already stored in the collection of TL IMV NASU, and for isolates that will be isolated from various man-made substrates. Such an approach will allow to use cultures with high enzyme activity and obtain more accurate results when testing the funginertness of materials. Thus, using as a test culture of C. globosum F-41224 isolate is more appropriate than C. globosum F-16714, whose cellulase activity is somewhat lower.

A number of researchers $[6,22,23,24]$ believes that active materials destructors are strains isolated from its surface with a high incidence of occurrence. This statement is not always true, since it is unknown whether culture 
develops at the expense of the technical material itself, or at the expense of more affordable compounds formed during its decomposition by true destructors. Clarification of this issue is also possible due to the evaluation of the enzymatic activity of the selected culture.

The results of screening of collection of test-cultures of microscopic fungi can serve as the beginning of biotechnological development, since EI of hydrolytic enzymes of most investigated isolates were at the producer level (higher than 1,5).

Among them $A$. versicolor F-41469, A. pullulans F-159 i C. cladosporioides F-41230 had high cellulase activity, A. versicolor (F-41469 та F-16718), $H$. resinae F-16724, $P$. variotii F-16724, $P$. aurantiogriseum F-1644, P. chrysogenum F-16719 and P. funiculosum F-16721 - significant amylase activity, A. pullulans F-159, C. cladosporioides F-41230, both strains of C. sphaerosphermum (F-41232 i F-2442), P. aurantiogriseum F-1644, P. chrysogenum F-16719, P. funiculosum F-16721 and P. ochrochloron F- 16715 - high lipase activity. Our findings are consistent with the results of other researchers [19-21].

Information on the enzymatic activity of micromycetes isolated from the gypsum plasterboard allows to understand how the damage occurs to this material. According to the literature, gypsum plasterboard contains a significant amount of components available for digestion by the microscopic fungi [25]. Thus, cardboard for action of cellulase can be cleaved to glucose, pentose or oligocycrids, starch and dextrin under the action of amylase are cleaved to mono- or oligocycraids; polyvinyl acetate and polysorbate TWIN-80 - under the influence of lipases is converted into alcohols and fatty acids.

These low molecular weight readily available components that are formed during the destruction of gypsum plasterboard can support not only the development of specific destructors, but also promote the growth of a wide range of microorganisms.

Conclusions. Thus, screening of the ability of 31 culture of microscopic fungi to produce hydrolytic enzymes has been carried out.

It has been found that the enzymatic activity of the isolates, with the exception of $C$. globosum F-16714, did not depend on the storage period and the source of isolation.

It has been shown that all investigated isolates are suitable for use as a test culture for assessing the fungicide resistance of technical materials, they are characterized by the presence of at least one enzymatic activity (cellulase, amylase, lipase or protease).

It has been found that $A$. versicolor F-41469 can be potential producer of cellulases and amylases, A. pullulans F-159 i C. cladosporioides F-41230 cellulases and lipases, $P$. aurantiogriseum F-1644, P. chrysogenum F-16719 i P. funiculosum - amylases and lipases, H. resinae F-16724, P. variotii F-16724only amylases, C. sphaerosphermum (F-41232 та F-2442) та P. ochrochloron F- 16715 - only lipases. There were no potential protease producers among investigated isolates.

It has been established that the vast majority of strains isolated from drywall are potential destructors of its main components. 


\title{
ЗДАТНІСТЬ МІКРОСКОПІЧНИХ ГРИБІВ, РЕКОМЕНДОВАНИХ ДЛЯ ОЦІНКИ ГРИБОСТІЙКОСТІ ТЕХНІЧНИХ МАТЕРІАЛІВ, УТВОРЮВАТИ ГІДРОЛІТИЧНІ ФЕРМЕНТИ
}

\author{
А.І. Чуєнко, Ю.Б. Письменна \\ Інститут мікробіології і вірусологї ім. Д.К. Заболотного НАН Украӥни, \\ вул. Заболотного, 154, Київ, 03143, Україна \\ Резюме
}

Мета. Оцінити активність гідролітичних ферментів тест-культур мікроскопічних грибів, що застосовують для випробувань з грибостійкості технічних виробів і матеріалів. Методи. Ферментативні активності (комплексів целюлаз, амілаз, ліпаз та протеаз) визначали відповідно до методів, заснованих на реакції між барвником, що вносять у середовище або на колонію, та продуктом розкладу субстрату, та розраховували ензиматичний індекс. Результати. Виявлено, що всі досліджені ізоляти характеризувалися наявністю принаймні однієї ферментативної активності (целюлазної, амілазної, ліпазної або протеазної). Висновки. Встановлено, що ензиматичні активності ізолятів, за винятком C. globosum F-16714, не залежали від терміну їх зберігання та джерела виділення. Виявлено, що A. versicolor F-41469 мав найбільші значення целюлазної та амілазної активності, A. pullulans F-159 та C. cladosporioides F-41230 - целюлазної та ліпазної, P. aurantiogriseum F-1644, P. chrysogenum F-16719 та $P$. funiculosum - амілазної та ліпазної, H. resinae F-16724, P. variotii F-16724 - амілазної, C. sphaerosphermum (F-41232 та F-2442) та P. ochrochloron F- 16715 - ліпазної. Встановлено, що переважна більшість штамів, виділених з гіпсокартону, є потенційними деструкторами його основних компонентів.

Ключові слова: грибостійкість, гіпсокартон, гідролітичні ферменти, ензиматичний індекс, біодеструкція.

\section{СПОСОБНОСТЬ МИКРОСКОПИЧЕСКИХ ГРИБОВ, РЕКОМЕНДОВАННЫХ ДЛЯ ОЦЕНКИ ГРИБОСТОЙКОСТИ ТЕХНИЧЕСКИХ МАТЕРИАЛОВ, ОБРАЗОВЫВАТЬ ГИДРОЛИТИЧЕСКИЕ ФЕРМЕНТЫ}

\author{
А.И. Чуенко, Ю.Б. Письменная \\ Институт микробиологии и вирусологии им. Д.К. Заболотного НАН Украины, \\ ул. Заболотного, 154, Киев, 03143, Украина \\ Резюме \\ Цель. Оценить активность гидролитических ферментов тест-культур микрос- \\ копических грибов, используемых для испытаний грибостойкости технических из- \\ делий и материалов. Методы. Ферментативные активности (комплексов целлюлаз, \\ амилаз, липаз и протеаз) определяли в соответствии с методами, основанными на ре- \\ акции между красителем, который вносят в среду или на колонию, и продуктом раз- \\ ложения субстрата, и рассчитывали энзиматический индекс. Результаты. Выявлено, \\ что все исследованные изоляты характеризовались наличием хотя бы одной фер- \\ ментативной активности (целлюлазной, амилазной, липазной или протеазной).
}


Выводы. Определено, что энзиматические активности изолятов, за исключением C. globosum F-16714, не зависели от срока их хранения и источника выделения. Выявлено, что $A$. versicolor F-41469 имел наибольшие значения целлюлазной и амилазной активности, A. pullulans F-159 и C. cladosporioides F-41230 - целлюлазной и липазной, P. aurantiogriseum F-1644, P. chrysogenum F-16719 и P. funiculosum - амилазной и липазной, $H$. resinae $F-16724, P$. variotii $F-16724$ - амилазной, C. sphaerosphermum (F-41232, F-2442) и P. ochrochloron F-16715 -липазной. Установлено, что большинство штаммов, выделенных из гипсокартона, являются потенциальными деструкторами его основных компонентов.

Ключевые слова: грибостойкость, гипсокартон, гидролитические ферменты, энзиматический индекс, биодеструкция.

1. Zaikov GE. Gorenie, destruktsiya i stabilizatsiya polimerov. S.-Pb.: Nauchnyye osnovy i tekhnologii; 2008. Russian.

2. Bilay VI., Koval EZ. Aspergilly. K.: Nauk. dumka; 1988. Russian.

3. Koval EZ., Rudenko AV, Goncharuk VV. Penitsyliyi v navkolyshn'omu seredovyshchi (Part 1). K.: Nauk. dumka; 2014. Ukranian.

4. Sergeev AYu., Sergeev YuV. Gribkovyie infektsii. 2nd ed. M.: BINOM; 2008. Russian.

5. Smirnov VF., Semicheva AS., Smirnova ON., Pertseva AD. K voprosu otsenki gribostoykosti materialov $\mathrm{V}$ nekotoryih otechestvennyih standartnyih metodah ispyitaniy. Mikologiya i fitopatologiya. 2000; 34(6): 50-5. Russian.

6. Turkova ZA. Titkova OA. Vzaimootnosheniya vidov gribov, primenyaemyih dlya ispyitaniya tehnicheskih izdeliy $i$ ih antibioticheskie svoystva. In: Mikroorganizmyi i nizshie rasteniya - razrushiteli materialov i izdeliy. M.: Nauka; 1979. p. 33-46. Russian.

7. Feldman MS. Sravnitelnoe issledovanie aktivnosti nekotorih oksidoredyktaz i gidrolaz mikromicetov v svyazi s biopovrejdeniem promishlennih materialov. Thesis of $\mathrm{PhD}$ dissertation, Voronej, 1987. Russian

8. Lugauskas AYu. Repechkene YuP. Mikroskopicheskie gribyi, povrezhdayuschie polimernyie materialyi v estestvennyih usloviyah. In: Biologicheskoe povrezhdenie materialov. Vilnyus; 1979. p. 65-71. Russian.

9. Egorov NS., editors. Promyishlennaya mikrobiologiya. M.: Vyissh. shkola; 1989. Russian.

10. GOST 9.050-75. Varnish and paint coatings. Laboratory test methods to mould resistance. M.: Izd-vo standartov, 1975.

11. GOST 9.085-78. Cooling lubricant. Bioresistance test methods. M.: Izd-vo standartov, 1978.

12. GOST 9.052-88. Oils and greaeses. Laboratory test methods for mould resistance. M: Izd-vo standartov, 1988.

13. GOST 9.048-89. Technical items. Methods of laboratory tests for mould resistance. M: Izd-vo standartov, 1989.

14. GOST 9.049-91. Polymer materials and their components. Methods of laboratory tests for mould resistance. M: Izd-vo standartov, 1992.

15. Pismennaya YuB., Subbota AG., Nakonechnaya LT. Mikobiota pri izuchenie gribostoykosti gipsokartona. Mikrobiol. Z. 2015; 77(5):55-61. Russian.

16. Bilay VI., editors. Metodyi eksperimentalnoy mikologii. K.: Nauk. dumka; 1982. Russian. 
17. Hankin L., Anagnostakis SL. The use of solid media for detection of enzyme production by fungi. Mycologia. 1975; 67(3):597-11.

18. Rohrmann S., Molitoris HP. Screening for wood-degrading enzymes in marine fungi. Can. J. Bot.1992; 70(10): 2116-8.

19. Colonia BSO., Chagas AFJr. Screening and detection of extracellular cellulases (endo- and exo-glucanases) secreted by filamentous fungi isolated from soils using rapid tests with chromogenic dyes. Afr. J. Biotechnol. 2014; 52(13): 4694-8.

20. Florencio C., Couri S., Farinas CS. Correlation between agar plate screening and solidstate fermentation for the prediction of cellulase production by Trichoderma strains. Enzyme Research. 2012 Oct 31. doi:10.1155/2012/793708. Article ID 793708.

21. Lumi ACA., Faria C. Fernandes de Castro F., Regina de Souza S., dos Santos FC., da Silva CN., Tessmann DJ., et al. Fungi isolated from maize (Zea mays L.) grains and production of associated enzyme activities. Int. J. Mol. Sci. 2015; 16(7):15328-19.

22. Kanevskaya IG. Biologicheskoe povrezhdenie promyshlennyh materialov. L.: Nauka; 1984. Russian.

23. Kurakov AV., Gevorkyan SA., Goginyan VB., Ozerskaya SM. Raznoobrazie i osobennosti sostava mikroskopicheskih gribov na sinteticheskih polimernyh materialah. Prikl. biohim. i mikrobiol. 2008; 44(2):232-4. Russian.

24. Lugauskas A., Levinskaite L., Pečiulyte D. Micromycetes as deterioration agents of polymeric materials. Int. Biodeterior Biodegradation. 2003;52(4): 233-10.

25. Hummel, Hans-Ulrich, inventor. Gypsum product. patent PCT/EP2007/052934 (DE). 2007 Oct 4.

Отримано 10.11.2017 